\title{
IMPLEMENTASI PROGRAM KOTA TANPA KUMUH (KOTAKU) DALAM MENANGGULANGI KAWASAN KUMUH DI KELURAHAN TANJUNG MAS KOTA SEMARANG
}

\author{
Herta Sitorus $^{1^{*}}$, Retno Sunu Astuti ${ }^{1}$, Hartuti Purnaweni ${ }^{1,2}$ \\ ${ }^{1}$ Magister Administrasi Publik, FISIP, Universitas Diponegoro \\ ${ }^{2}$ Program Studi Ilmu Lingkungan, Sekolah Pascasarjana, Universitas Diponegoro \\ *Coressponding Author, email : $\underline{\text { herta.sitorus@yahoo.co.id }}$
}

\begin{abstract}
Abstrak
Tujuan penelitian ini adalah untuk menganalisis bagaimana Implementasi Program Kotaku di Kelurahan Tanjung Mas Kota Semarang, serta menidentifikasi faktor-faktor apa saja yang menjadi penghambat maupun pendukung dalam implementasi program Kotaku di Kelurahan Tanjung Mas. Penelitian yang merupakan penelitian deskriptif kualitatif ini menggunakan teknik pengumpulan data primer (observasi dan wawancara) serta data sekunder. Hasil penelitian menunjukkan bahwa implementasi program Kotaku di Kelurahan Tanjung Mas sejauh ini sudah berjalan dengan baik, mulai dari tahapan persiapan, perencanaan hingga tahap pelaksanaan. Dukungan dari masyarakat juga sangat baik terhadap program ini. Namun dalam implementasinya masih terdapat beberapa permasalahan diantaranya terkait penetapan area yang masuk delineasi kumuh, dan ada area yang masih menjadi sengketa dengan PT.KAI dan sebagian wilayah Kelurahan Tanjung Mas yang masuk dalam program Nasional Kampung Bahari, sehingga program Kotaku tidak bisa di implementasikan di daerah tersebut. Rekomendasi yang bisa diberikan adalah; melakukan pembaruan data, verifikasi ulang dan kerjasama dengan pihak-pihak terkait kejelasan tentang sengketa lahan dan persiapan perencanaan program yang jauh lebih matang.
\end{abstract}

Kata Kunci: Implementasi, Kawasan Kumuh, Program Kotaku

\begin{abstract}
The purpose of this study is to analyze how the implementation of the Kotaku Program in the Tanjung Mas Urban District of Semarang City, as well as identify what factors are obstacles or supporters in the implementation of the Kotaku program in the Tanjung Mas Urban Village. This descriptive qualitative research uses primary data collection techniques (observation and interviews) as well as secondary data. The results showed that the implementation of the Kotaku program in Tanjung Mas has so far been going well, starting from the preparation, planning and implementation stages. Support from the community is also very good for this program. However, in the implementation there are still some problems including the determination of areas that are included in slum delineation, and there are areas that are still in dispute with PT. KAI and parts of the Tanjung Mas Kelurahan which are included in the Kampung Bahari National program, so that the Kotaku program cannot be implemented in the regions. the. Recommendations that can be given are; updating data, re-verifying and collaborating with related parties regarding clarity on land disputes and preparing a much more mature program planning. Keywords: Implementation, Slums, Kotaku Program
\end{abstract}


Jurnal Administrasi Negara

ISSN : 2598-4039 (Online)

ISSN : 2302-2231 (Print)
Herta Sitorus, Retno Sunu Astuti dan

Hartuti Purnaweni

Universitas Diponegoro

\section{PENDAHULUAN}

Permukiman kumuh menjadi permasalahan klasik di kota-kota besar. Meskipun demikian, permukiman kumuh tetap saja menjadi masalah utama bagi pengembangan kota. Pasal $28 \mathrm{H}$ Ayat 1 (Undang-Undang Dasar Negara Republik Indonesia, 1945), menyatakan bahwa: "Setiap orang berhak untuk hidup sejahtera lahir dan batin, bertempat tinggal, dan mendapatkan lingkungan hidup yang baik dan sehat, serta berhak memperoleh pelayanan kesehatan". Upaya mengentaskan pemukiman kumuh merupakan salah satu target Nasional yang dimuat dalam Rencana Pembangunan Jangka Menengah Nasional (RPJMN) tahun 2015-2019. Salah satu sasaran pembangunan kawasan permukiman adalah tercapainya pengentasan permukiman kumuh menjadi 0 (nol) hektar dari 38.431Ha luas kawasan permukiman kumuh yang tersebar diseluruh wilayah Indonesia. Ditjen Cipta Karya (DJCK) Kementerian Pekerjaan Umum dan Perumahan Rakyat (PUPR) melakukan inisiasi pembangunan platform kolaborasi yang fokusnya adalah mewujudkan permukiman layak huni tanpa menggusur, melalui Program Kota Tanpa Kumuh (Kotaku).

Program Kotaku merupakan upaya strategis DJCK untuk mempercepat penanganan permukiman kumuh di Indonesia, serta mendukung “Gerakan 100-0-100", yaitu 100\% akses universal air minum, 0\% permukiman kumuh, dan $100 \%$ akses sanitasi layak. Melalui program ini DJCK membangun sistem, memfasilitasi pemerintah daerah, dan memfasilitasi komunitas, melalui peningkatan peran pemerintah daerah dan partisipasi masyarakat. Arah Kebijakan Program Kotaku untuk tahun anggaran 2019 ini adalah membangun infrastruktur permukiman Skala Kawasan sehingga diharapkan dapat mengubah wajah kawasan permukiman. (Kementerian Pekerjaan Umum dan Perumahan Rakyat, 2019a). Program Kotaku dilaksanakan di 34 provinsi, tersebar di 269 kabupaten/kota, pada 11.067 desa/kelurahan termasuk di Kota Semarang. (Kementerian Pekerjaan Umum dan Perumahan Rakyat, 2019b)

Kota Semarang merupakan salah satu yang melaksanakan program Kotaku, melalui Surat Keputusan Walikota Semarang Nomor 050/801/2014 tentang Penetapan lokasi lingkungan perumahan dan permukiman kumuh Kota Semarang, di Kota Semarang terdapat kawasan kumuh seluas 415,83 hektar, tersebar di 15 Kecamatan dan 62 Kelurahan. Luasan kumuh terluas berada di Kelurahan Tanjung Mas yaitu 37,63 Ha. 
Jurnal Administrasi Negara

ISSN : 2598-4039 (Online)

ISSN : 2302-2231 (Print)
Herta Sitorus, Retno Sunu Astuti dan

Hartuti Purnaweni

Universitas Diponegoro
Permasalahan-permasalahan yang teridentifikasi di Kelurahan Tanjung Mas antara lain: permasalahan jalan dan drainase lingkungan, prasarana pengelolaan air limbah (sanitasi), pengelolaan sarana persampahan, dan pengamanan bahaya kebakaran.

Telah dilakukan berbagai penelitian tentang program Kotaku (Yuliani \& Rosyida, 2017), (Irfani \& Winarni, 2018), (Bathari et al., 2018) menunjukkan bahwa program Kotaku sudah dilaksanakan di Yogyakarta, Surakarta dan Kendari dengan hasil yang bervariasi. Sebagian berhasil, sebagian belum misalnya dalam aspek penanganan kawasan yang masih rentan terhadap bahaya kebakaran. Komunikasi yang masih kurang baik antar pemangku kepentingan, dan lain sebagainya. Terdapat perbedaan mendasar antara penelitian ini dengan penelitian-penelitian sebelumnya, penelitian ini fokus pada implementasi program Kotaku dalam upaya menanggulangi kawasan kumuh dan faktor apa saja yang menjadi pendukung dan penghambat implementasi program Kotaku, lokus penelitian yang dipilih adalah di Kelurahan Tanjung Mas kota Semarang. Kemudian untuk menganalisis implementasi program Kotaku, menggunakan Tahapan Implementasi Program Kotaku, dan untuk menganalisis Faktor yang menjadi pendukung dan Penghambat implementasi program Kotaku menggunakan model Implementasi Kebijakan Donald S. Van Meter dan Carl E. Van Horn (Agustino, 2016).

Tujuan Penelitian ini berfokus pada dua hal yaitu: (i) implementasi program Kota Tanpa Kumuh (KOTAKU) dalam menanggulangi Kawasan Kumuh di Kelurahan Tanjung Mas Kota semarang, dan (ii) menganalisis faktor-faktor apa saja yang menjadi pendukung dan penghambat dalam pengimplementasian program Kota Tanpa Kumuh (KOTAKU) di Kelurahan Tanjung Mas Kota Semarang. Penelitian ini merupakan penelitian deskriptif dengan pendekatan kualitatif dan berusaha untuk menganalisis Implementasi program Kotaku di Kelurahan Tanjung Mas. Instrumen dalam menelitian ini menggunakan daftar pertanyaan (interview guide) serta telaah terhadap dokumen pendukung lainnya. Subjek penelitian yaitu informan yang berjumlah 12 Orang dipilih dengan teknik Purposive Sampling, yaitu 1 orang dari BAPPEDA, 2 orang Tim NUSP (Neighborhood Upgrading and Shelter Project), 1 Orang Tim NSUP (National Slum Upgrading Program), 7 orang Perangkat Desa/Kelurahan dan 1 orang Badan Keswadayaan Masyarakat 
Jurnal Administrasi Negara

ISSN : 2598-4039 (Online)

ISSN : 2302-2231 (Print)
Herta Sitorus, Retno Sunu Astuti dan

Hartuti Purnaweni

Universitas Diponegoro
(BKM). Teknik pengumpulan data melalui studi pustaka dengan melakukan serangkaian kegiatan membaca, menelaah dan mengutip dari bahan kepustakaan serta pengkajian terhadap ketentuan peraturan perundang-undangan yang berkaitan dengan pokok bahasan, observasi, wawancara mendalam dan dokumentasi. Teknik analisis data yang digunakan yaitu teknik analisa data kualitatif model Spradley secara keseluruhan proses penelitian terdiri atas: pengamatan deskriptif, analisis domein, pengamatan terfokus, analisis taksonomi, pengamatan terpilih, analisis komponensial, dan diakhiri dengan analisis tema (Moleong, 2010). Proses tersebut dapat disederhanakan dalam empat tahap sebagai berikut: (i) Analisis Domein, (ii) Analisis Taksonomi, (iii) Analisis Komponen, dan (iv) Analisis Tema, untuk mendapatkan hasil penelitian yang kredibel.

Implementasi Program Kotaku di Kelurahan Tanjung Mas berdasarkan SK Walikota Semarang Nomor 050/801/2014 tentang penetapan lokasi lingkungan perumahan dan permukiman kumuh Kota Semarang. Sasaran kebijakan adalah pengentasan permukiman kumuh menjadi 0 (nol) hektar melalui penanganan kawasan permukiman kumuh seluas 415,83 Ha di Kota Semarang. Kelurahan Tanjung Mas merupakan

wilayah/delineasi penanganan kumuh prioritas, dikarenakan Kelurahan Tanjung Mas memiliki wilayah kumuh paling luas yaitu 37,63 Ha. Kelurahan Tanjung Mas terdiri dari 16 RW yang terbagi menjadi dua wilayah yaitu Kebon Harjo dengan 11 RW dan Tambak Lorok 5 RW. Analisis Implementasi Program Kotaku di kelurahan Tanjung Mas meliputi tahapan Implementasi Program Kotaku. Ada 3 tahap dalam Implementasi program Kotaku yaitu : Tahap Persiapan, tahap perencanaan, dan tahap pelaksanaan.

\section{Tahap Persiapan}

Berdasarkan wawancara dengan beberapa informan dari implementor Program Kotaku di Kelurahan Tanjung Mas, diketahui bahwa tahap persiapan implementasi program Kotaku di Kelurahan Tanjung Mas meliputi dua kegiatan yaitu; (a) Sosialisasi; (b) Pembentukan/penguatan Tim Inti Perencanaan Partisipatif (TIPP). Diawali dengan kegiatan Sosialisasi yang dilakukan melalui berbagai kegiatan, dimulai dengan mempersiapkan Pemetaan pelaku yang terkait dengan isu kekumuhan di Kelurahan Tanjung Mas. Pelaku tersebut berperan sebagai agen sosialisasi dan Tim Inti Perencanaan Partisipatif (TIPP). Selanjutnya, menyamakan pemahaman mengenai kondisi atau skala kumuh di 
Jurnal Administrasi Negara

ISSN : 2598-4039 (Online)

ISSN : 2302-2231 (Print)
Herta Sitorus, Retno Sunu Astuti dan

Hartuti Purnaweni

Universitas Diponegoro
Kelurahan Tanjung Mas. Proses selanjutnya, melakukan kajian awal terhadap berbagai instansi dan program yang sudah dan sedang dilaksanakan oleh Pemerintah. Tahapan sosialisasi dilakukan melalui berbagai kegiatan, media dan dilakukan dari tingkat Kecamatan atau Kelurahan hingga ke tingkat lingkungan. Tujuannya adalah agar seluruh pihak memahami pentingnya lembaga perencanaan permukiman di Kelurahan Tanjung Mas serta membangkitkan kesadaran warga untuk peduli dan memiliki keterampilan dibidang permukiman, serta terlibat aktif dalam perencanaan permukiman.

Selanjutnya,

pembentukan/penguatan Tim Inti Perencanaan Partisipatif (TIPP) yang beranggotakan masyarakat Kelurahan Tanjung Mas. TIPP terdiri dari beberapa Kelompok Kerja (Pokja) yang sesuai dengan kebutuhan masyarakat. TIPP di Kelurahan Tanjung Mas ada 15 orang terdiri dari 5 orang perempuan dan 10 orang laki-laki.

\section{Tahap Perencanaan}

Menurut Sjafrizal (Sjafrizal, 2009) perencanaan pembangunan adalah cara untuk mencapai tujuan pembangunan secara tepat, terarah, dan efisien sesuai dengan kondisi daerah bersangkutan. Berdasarkan wawancara dengan beberapa informan dari implementor program kotaku di Kelurahan Tanjung Mas, diketahui bahwa metode perencanaan implementasi program Kotaku di Kelurahan Tanjung Mas adalah membuat kegiatan rembug Warga, diskusi kelompok dan kegiatan inovatif lainnya. Disampaikan juga bahwa Pelaksana Implementasi Program Kotaku di Kelurahan Tanjung Mas adalah Lurah, Badan Keswadayaan Masyarakat (BKM) atau lembaga Keswadayaan Masyarakat (LKM), Tim Inti Perencana Partisipatif (TIPP) dan pesertanya adalah masyarakat. Narasumber Program Kotaku adalah Pokja PKP, Pemerintah Daerah, Perguruan Tinggi, Lembaga Swadaya Masyarakat (LSM) dan kelompok relawan lainnya. Perencanaan Implementasi Program Kotaku di Kelurahan Tanjung Mas dimulai sejak tahun 2015. Tahap perencanaan implementasi program Kotaku di Kelurahan tanjung mas dilakukan dengan beberapa proses, dimulai dengan merumuskan kondisi permukiman layak huni yang diinginkan Masyarakat, dengan melakukan Survey Kampung Sendiri (SKS), hal ini bertujuan untuk menampung usulan dari masyarakat. Kemudian melakukan review terhadap usulan-usulan tersebut agar dapat menentukan program mana yang jadi 
Jurnal Administrasi Negara

ISSN : 2598-4039 (Online)

ISSN : 2302-2231 (Print)
Herta Sitorus, Retno Sunu Astuti dan

Hartuti Purnaweni

Universitas Diponegoro prioritas saat pelaksanaan nantinya. Hasil review tersebut kemudian disusun dalam sebuah dokumen yang disebut Neigborhood Upgrading Action Plan (NUAP) dan Rencana Penataan Lingkungan Permukiman/Rencana Tindak Penataan Lingkungan Permukiman (RPLP / RTPLP).

Tujuan perencanaan Implementasi Program Kotaku yaitu membuat dan menyelaraskan visi dan misi masyarakat dengan visi dan misi pembangunan permukiman pemerintah pusat yang dituangkan dalam Rencana Penataan Lingkungan Permukiman (RPLP) dan Rencana Tindak Penataan Lingkungan Permukiman (RTPLP). Dokumen RPLP/RPP/PJM Kumuh atau perencanaan yang setara, merupakan rencana yang memuat arahan pencegahan dan rencana peningkatan kualitas permukiman kumuh yang terintegrasi.

Perencanaan juga mengacu pada dokumen aturan bersama yaitu memuat aturan-aturan kesepakatan bersama di tingkat komunitas. Aturan tersebut diikuti secara konsisten untuk mewujudkan lingkungan permukiman yang layak huni. Proses sinkronisasi diselenggarakan melalui media forum konsultasi secara berkala. Forum konsultasi dapat dilakukan pada setiap tahapan perencanaan untuk konsolidasi penyepakatan bersama penyelesaian persoalan-persoalan yang terjadi. Berdasarkan hasil wawancara dengan beberapa informan, dapat diketahui bahwa forum konsultasi bersifat fleksibel, ketika ada sesuatu yang harus disampaikan maka segera dikomunikasikan.

Masyarakat juga sangat berperan aktif, ketika pengerjaan di lapangan mengalami kekurangan atau kendala mereka segera menyampaikan kepada BKM untuk segera ditindaklanjuti. Sementara untuk pelaporan progres berupa program fisik dilapangan sejauh ini dilakukan setiap minggu kepada koordinator kota yang diteruskan ke pihak DISPERKIM dan BAPPEDA. Pelaporan progres tersebut meliputi capaian program dan kendala-kendala yang dihadapi dilapangan, ketika terdapat kendala sesegera mungkin diselesaikan. Proses perencanaan selanjutnya adalah melakukan pemetaan forum, kelompok atau organisasi pemerhati pembangunan untuk didayagunakan dalam implementasi Program di lapangan.

Adapun tahapan penyelenggaraan forum konsultasi di Kelurahan Tanjung Mas yaitu melakukan pemetaan forum forum, kelompok-kelompok atau organisasi pemerhati pembangunan yang sudah terbentuk, forum-forum tersebut didayagunakan oleh tim perencana untuk melakukan konsultasi 
Jurnal Administrasi Negara

ISSN : 2598-4039 (Online)

ISSN : 2302-2231 (Print)
Herta Sitorus, Retno Sunu Astuti dan

Hartuti Purnaweni

Universitas Diponegoro dan sosialisasi terkait persoalan dan kendala penanganan permukiman kumuh yang perlu didiskusikan bersama.

Forum konsultasi wajib melibatkan anggota Pokja PKP sesuai tugas pokoknya. Rencana pembentukan forum pemerhati Implementasi Program Kotaku di Kelurahan Tanjung Mas diantaranya forum air minum akan dilayani oleh PDAM. Forum Penataan jaringan jalan, drainase, sanitasi akan dikerjakan oleh BKM/LKM, TIPP, dan tim pelaksana program Kotaku yang bertugas di Kelurahan Tanjung Mas. Persampahan di Kelurahan Tanjung Mas ditangani oleh Dinas Lingkungan Hidup (DLH), Selanjutnya forum pengamanan bahaya kebakaran.

Tahap berikutnya memastikan anggota Pokja PKP melakukan bimbingan teknis kepada tim perencana tingkat kelurahan sekaligus melakukan sosialisasi hasil kesepakatan perencanaan RP2KPKP secara berkala kepada tim Perencana penyusunan RPLP dan RTPLP. Pelaksanaan penanganan permukiman kumuh di kelurahan akan dibantu oleh BKM/LKM, TIPP, serta lembaga yang ada di kelurahan/desa atau di wilayah kecamatan, para implementor program Kotaku diberikan pelatihan kurang lebih selama seminggu. pelatihan ini diberikan oleh Koordinator Kota, dan diikuti oleh Badan Keswadayaan Masyarakat (BKM) yang menerima program, Kelompok Swadaya Masyarakat (KSM), dan Tim Inti Perencanaan Partisipatif (TIPP). Bimbingan teknis ini bertujuan agar para implementor dapat melaksanakan tugas dan fungsinya dengan baik dilapangan.

\section{Tahapan Pelaksanaan}

Menurut Westra, dkk (Adisasmita, 2011) pelaksanaan merupakan usaha yang dilakukan untuk melaksanakan rencana dan kebijaksanaan yang telah dirumuskan dan ditetapkan dengan melengkapi segala kebutuhan alat-alat yang diperlukan, siapa yang akan melaksanakan, dimana tempat pelaksanaannya dan kapan waktu dimulainya. Kegiatan dilaksanakan dengan transparan dan akuntabel. Kegiatan yang telah dilaksanakan harus dipertanggungjawabkan dan disusun dalam bentuk laporan hasil kerja atau pencapaian. Tahapan pelaksanaan dilaksanakan sesuai apa yang tertuang di RPLP dengan melaksanakan kegiatan-kegiatan yang bersifat prioritas dalam penanganan kawasan kumuh.

Berdasarkan hasil wawancara dengan beberapa implementor program Kotaku di Kelurahan Tanjung Mas, mereka menyampaikan bahwa Pelaksanaan Program Kotaku di 
Jurnal Administrasi Negara

ISSN : 2598-4039 (Online)

ISSN : 2302-2231 (Print)
Herta Sitorus, Retno Sunu Astuti dan

Hartuti Purnaweni

Universitas Diponegoro
Kelurahan Tanjung Mas meliputi kegiatan Infrastruktur, Ekonomi, dan sosial antara lain: (a) Kegiatan investasi infrastruktur skala lingkungan dan pemeliharaan hasil pembangunan di tingkat Kelurahan. (b) Kegiatan Ekonomi, dan (c) Kegiatan sosial, seperti pengembangan kapasitas di tingkat Kelurahan/Desa. Dari penyampaian implementor program Kotaku di Kelurahan Tanjung Mas diketahui bahwa sejauh ini dalam pelaksanaannya program Kotaku telah memberikan perubahan di Kelurahan tanjung Mas, pada tahun 2016 Program Kotaku berhasil mengurangi kawasan kumuh sebesar 1,1 Hektar, 2017 menangani 4,3 hektar, kemudian ditahun 2018 2,61 Hektar dan target pada tahun 2019 1,17 hektar. Sisa jumlah lokasi kumuh 28 hektar yaitu berada di Tambak Lorok yang belum dijamah oleh program Kotaku karena masih menunggu program Kampung Bahari. Namun untuk Bonharjo sudah baik, tinggal memikirkan kepadatan penduduk dan keteraturan bangunan.

Kegiatan investasi infrastruktur skala lingkungan dan pemeliharaan hasil pembangunan di Kelurahan Tanjung Mas meliputi $7+1$ indikator kumuh yaitu kondisi bangunan (keteraturan/kepadatan dan kondisi fisik), jalan, drainase, penyediaan air bersih, sanitasi, persampahan dan penerangan jalan, ruang terbuka publik dan pengamanan bahaya kebakaran. Penelitian kali ini fokus pada 5 indikator kumuh yang terdapat di Kelurahan Tanjung Mas, 5 indikator kumuh tersebut adalah: Sistem penataan jaringan jalan, penataan sistem drainase, prasarana pengelolaan air limbah (Sanitasi), Sistem pengelolaan dan prasarana persampahan, dan penyediaan prasarana pengamanan bahaya kebakaran.

Kondisi awal sistem jaringan jalan di Kelurahan Tanjung Mas sebagian telah rusak. Di Kelurahan Tanjung Mas terdapat jalan setapak yang rusak seluas $4.958,93 \mathrm{~m}^{2}$ dan jalan lingkungan yang rusak seluas $12.174 \mathrm{~m}^{2}$. Program Kotaku mulai mengubah wajah prasarana jalan umum (PJU) Kelurahan Tanjung Mas mulai pada tahun 2016 sebanyak 118 unit, pada tahun 2017 sebanyak 81 Unit, pada tahun 2018 sebanyak 31 Unit dan perbaikan jalan umum pada tahun 2019 sebanyak 811 unit perbaikan jalan paving. 
Jurnal Administrasi Negara ISSN : 2598-4039 (Online) ISSN : 2302-2231 (Print)

\section{Herta Sitorus, Retno Sunu Astuti dan \\ Hartuti Purnaweni \\ Universitas Diponegoro}
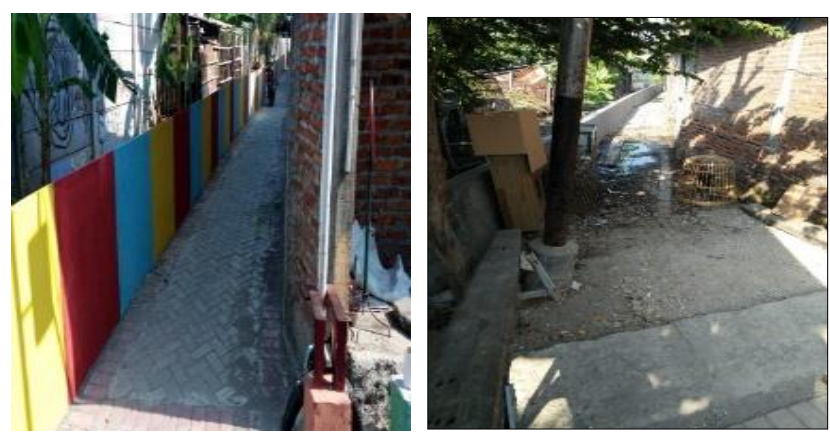

Sebelum

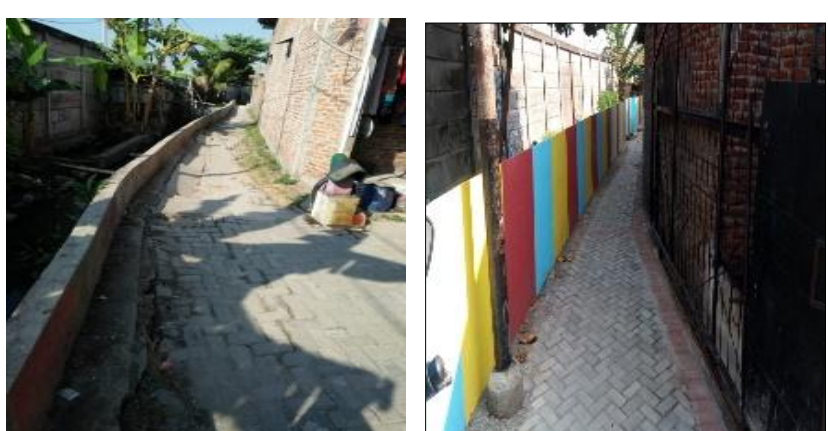

Sesudah

Gambar 1. Kondisi Jalan sebelum dan sesudah Implementasi Program Kotaku Sumber : Dokumentasi Tim NUSP, 2019

Masalah drainase di Kelurahan Tanjung Mas adalah, saluran drainase mengalami kerusakan dan menurunnya kapasitas yang disebabkan oleh sedimentasi, sampah, bangunan liar, dan rob. Hal ini karena meningkatnya beban drainase akibat alih fungsi lahan yang tidak diikuti dengan pengembalian fungsi resapan dan tampungan; intrusi air asin; gejala penurunan elevasi tanah (land subsidence); naiknya permukaan air laut sebagai dampak dari pemanasan global; operasi dan pemeliharaan yang kurang optimal; penegakan hukum (law enforcement) masih lemah. Terdapat drainase yang tidak berfungsi sebanyak $1.319,1 \mathrm{~m}^{2}$. Hal ini meyebabkan ketika musim penghujan aliran air yang berlebih tidak bisa dialirkan sehingga menyebabkan genangan bahkan banjir. Pada tahun 2016 program Kotaku di Kelurahan Tanjung Mas melakukan perbaikan drainase sepanjang $824 \mathrm{M}^{\prime}$, pada tahun 2017 dranase diperbaiki sepanjang 666,95M', pada 2018 sepanjang 568,00 $\mathrm{M}^{\prime}$ dan rencana pada tahun 2019 drainase akan dibangun sepanjang 819M'. Kegiatan tersebut meliputi perbaikan kualitas drainase, peninggian dan penggantian paving yang sudah tidak layak digunakan. 
Jurnal Administrasi Negara ISSN : 2598-4039 (Online) ISSN : 2302-2231 (Print)

\section{Herta Sitorus, Retno Sunu Astuti dan Hartuti Purnaweni \\ Universitas Diponegoro}
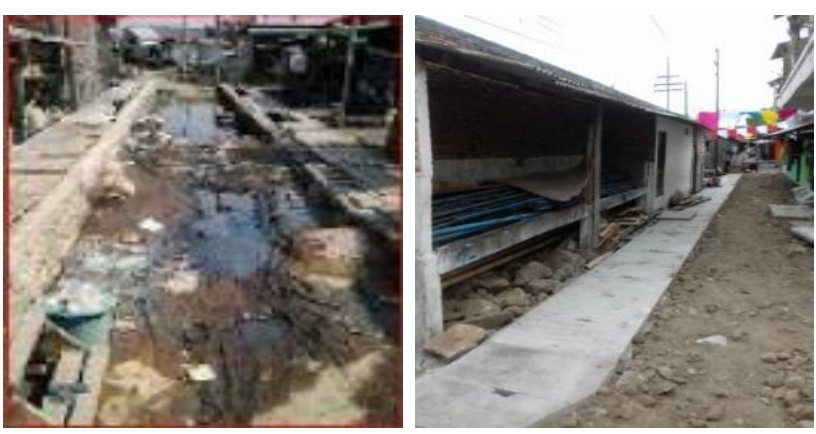

Sebelum
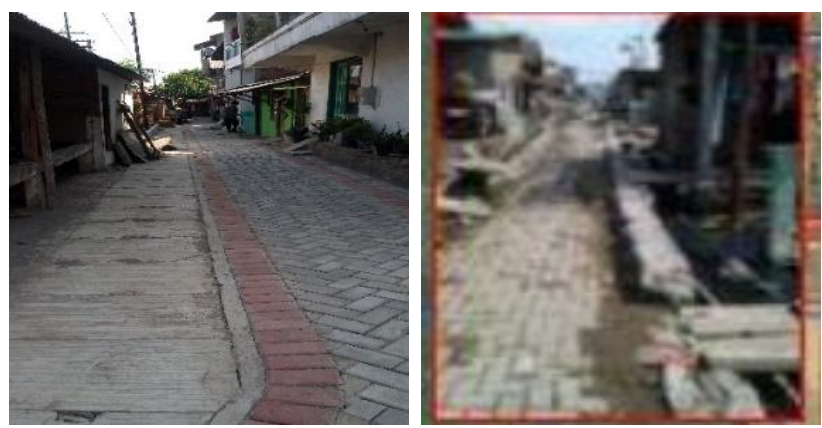

Sesudah

Gambar 2. Kondisi Drainase sebelum dan sesudah Implementasi Program Kotaku Sumber : Dokumentasi Tim NUSP, 2019

Permasalahan awal prasarana pengelolaan air limbah (Sanitasi) di Kelurahan Tanjung Mas adalah masih terdapat $116 \mathrm{KK}$ yang menggunakan MCK secara komunal atau berkelompok dan terdapat sekitar $174 \mathrm{KK}$ yang menggunakan WC dan IPAL secara komunal, dan masih terdapat beberapa WC umum yang tidak dilengkapi oleh
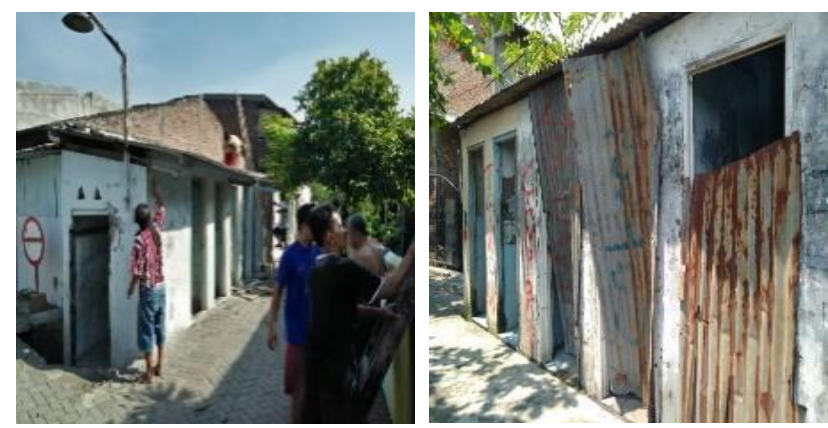

Sebelum sistem penampungan air besar/septic tank, bahkan kasus di wilayah Tambak Lorok masih banyak warga yang buang air besar di sungai karena keterbatasan lahan untuk Wc umum. Program Kotaku mengadakan perbaikan dan menambah MCK baru sebanyak 7 Unit, 2 MCK dibangun pada tahun 2016 dan 5 Unit pada tahun 2018.
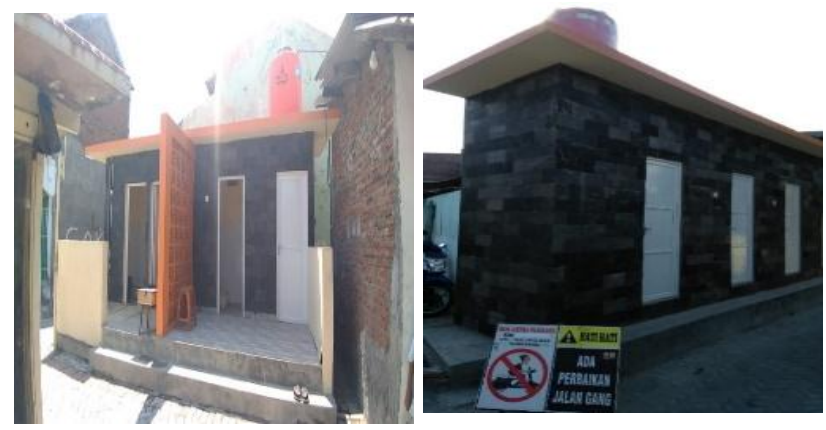

Sesudah

Gambar 3. Kondisi MCK sebelum dan sesudah implementasi program Kotaku Sumber : Dokumentasi Tim NUSP, 2019 
Jurnal Administrasi Negara

ISSN : 2598-4039 (Online)

ISSN : 2302-2231 (Print)

\section{Herta Sitorus, Retno Sunu Astuti dan}

Hartuti Purnaweni

Universitas Diponegoro
Permasalahan awal Sistem pengelolaan dan prasarana sampah rumah tangga di Kelurahan Tanjung Mas adalah masih kurang sadarnya masyarakat terhadap kebersihan, fasilitas yang sangat minim untuk lokasi TPS karena keterbatasan lahan dan pengelolaanya yang tidak jelas, belum tersedia tong sampah di masing-masing rumah. Program Kotaku pada tahun 2016 menyediakan 228 unit tong sampah yang tersebar di masing-masing rumah warga, menyediakan bak sampah di tempat pembuangan sampah
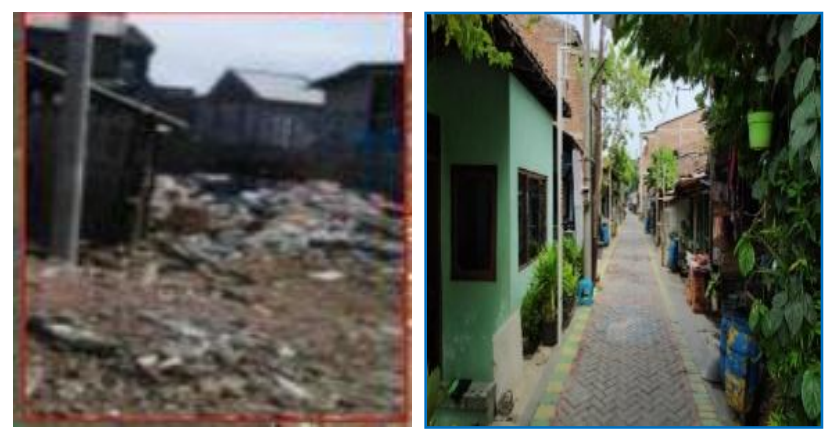

Sebelum sementara, pada tahun 2018 disediakan 1 unit becak sampah dan tahun 2019 disediakan 3 unit gerobak sampah. Namun sampai saat ini belum ada pengelolaan sampah di Kelurahan Tanjung Mas. Program Kotaku masih sebatas memberikan fasilitas prasarana persampahan, belum sampai pada tahap pengolahan sampah seperti daur ulang sampah menjadi sesuatu yang berharga dan bermanfaat. Konsep pengelolaan sampah pada umumnya dikenal dengan 4R (Reuse, Reduce, Recycle, Reflace).
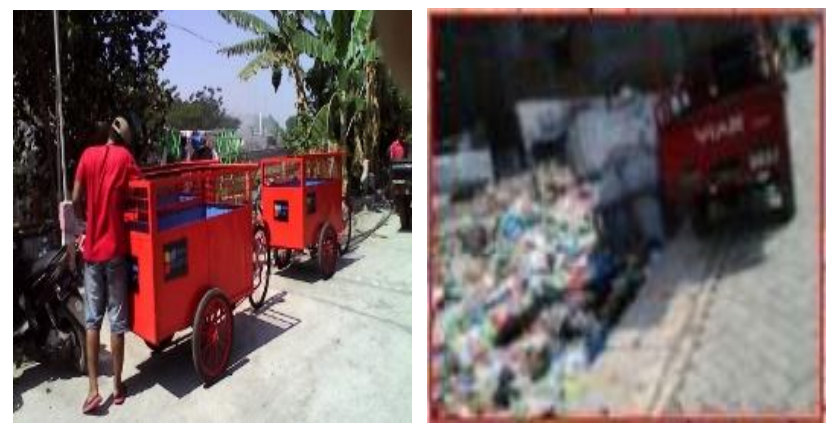

Sesudah

\section{Gambar 4. : Pengelolaan Sampah dan Prasarana Persampahan \\ Sebelum dan Sesudah Implementasi Program Kotaku}

Sumber : Dokumentasi tim NUSP, 2019

Tingkat hunian Kelurahan Tanjung Mas sangat padat yaitu antara 200-250 unit/per heaktar, lebar jalan kurang dari 4 Meter dan belum tersedia proteksi kebakaran. Dengan kepadatan bangunan tersebut tentunya sangat rentan terhadap bahaya kebakaran. Hal ini membuat Pemerintah dan Tim program Kotaku berkolaborasi dengan warga Tanjung Mas dan Dinas pemadam kebakaran untuk menyediakan prasarana pengaman bahaya kebakaran pada tahun 2019. Sosialisasi penyediaan prasarana 
Jurnal Administrasi Negara ISSN : 2598-4039 (Online)

ISSN : 2302-2231 (Print)
Herta Sitorus, Retno Sunu Astuti dan

Hartuti Purnaweni

Universitas Diponegoro pengaman bahaya kebakaran dilaksanakan pada bulan Februari 2019

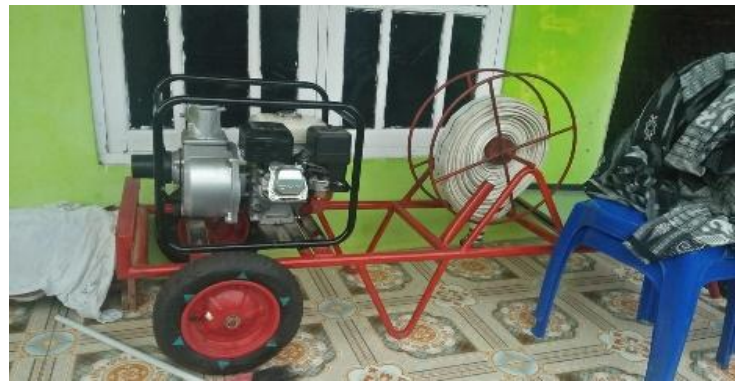

Alat Pemadam Kebakaran dan diadakan pelatihan kepada masyarakat pada bulan Maret 2019.

\section{Gambar 5. Alat Pemadam Kebakaran dan Proses Rapat Sosialisasi Pengadaan Alat Pemadam Kebakaran \\ Sumber : Diolah Peneliti, 2019}

Sumber pembiayaan Implementasi Program Kotaku adalah World Bank, Swadaya Masyarakat, APBN/APBD. Berdasarkan hasil wawancara dengan beberapa informan diketahui bahwa pembiayaan implementasi program Kotaku di Kelurahan Tanjung Mas pada tahun 2016 hingga tahun 2018 sebesar Rp. 1 Miliar tiap tahunnya, untuk pencairan setiap tahunnya terbagi menjadi dua siklus, masing-masing siklus sebesar Rp. 500 juta dengan kontrak 90 hari kerja. Terdapat Kendala yang terjadi di lapangan yaitu akses lingkungan yang sempit menyebabkan bahan material hanya bisa diturunkan di jalan besar, selanjutnya dilangsir menggunakan arco ke dalam gang/ke lokasi pembangunan. Selain menghambat progress pekerjaan, hal ini menyebabkan biaya tambahan untuk langsir material ke lokasi yang akan dibangun, sementara biaya tambahan untuk langsir material tersebut tidak termasuk dalam dana program.

Untuk mengentaskan pemukiman kumuh tidak cukup hanya melakukan pembangunan dan perbaikan infrastruktur, melainkan harus dilengkapi dengan kegiatan pemberdayaan dan penguatan Sumber daya Manusia. Berdasarkan hasil wawancara dengan beberapa informan diketahui bahwa Di Kelurahan Tanjung Mas, program Kotaku juga melakukan pembinaan kepada masyarakat. Pembinaan itu dilakukan dengan berbagai kegiatan antara lain: program 
Jurnal Administrasi Negara

ISSN : 2598-4039 (Online)

ISSN : 2302-2231 (Print)
Herta Sitorus, Retno Sunu Astuti dan

Hartuti Purnaweni

Universitas Diponegoro peningkatan kapasitas masyarakat, program kelembagaan mandiri, dan program pengembangan ekonomi lokal. Detail kegiatan yang dilakukan meliputi: pelatihan penguatan BKM/aparat kelompok/relawan, pelatihan TIPP, On The Job Training, pelatihan operasional \& pemeliharaan, pelatihan KSM, pelatihan komputer, keterampilan, pengelolaan keuangan, Coaching Clinic, FGD perubahan sikap dan perilaku, Livehood, dan pengembangan media sosialisasi warga.
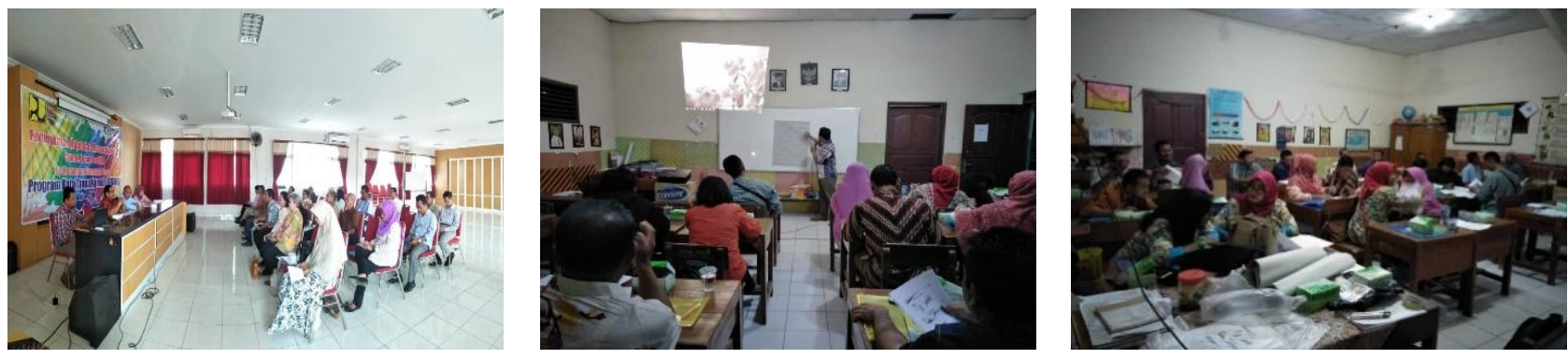

Gambar 6. Kegiatan Penguatan Kapasitas Masyarakat Sumber : Dokumentasi Tim NSUP, 2019

4. Faktor-Faktor Yang mendukung dan menghambat Implementasi Program Kota Tanpa Kumuh (Kotaku) Di Kelurahan Tanjung Mas Kota Semarang

Untuk menganalisis faktor yang mendukung dan menghambat implementasi program Kotaku di Kelurahan Tanjung Mas, Penelitian ini menggunakan model implementasi kebijakan menurut Donald Van Metter \& Carl van Horn (Agustino, 2016) .

\section{A. Ukuran Dan Tujuan Kebijakan}

Van Meter dan Van Horn (Agustino, 2016) mengemukakan untuk mengukur kinerja implementasi kebijakan tentunya menegaskan standar dan sasaran tertentu yang harus dicapai oleh para pelaksana kebijakan, kinerja kebijakan pada dasarnya merupakan penilaian atas tingkat ketercapaian standar dan sasaran tersebut.

Berdasarkan hasil wawancara dengan beberapa implementor program Kotaku di Kelurahan Tanjung Mas diketahui bahwa ukuran dan tujuan Program Kotaku di Kelurahan Tanjung Mas sudah jelas, arah kebijakan Program Kotaku adalah meningkatkan akses terhadap infrastruktur dan pelayanan dasar di permukiman kumuh untuk mendukung perwujudan permukiman yang layak huni, 
Jurnal Administrasi Negara

ISSN : 2598-4039 (Online)

ISSN : 2302-2231 (Print)
Herta Sitorus, Retno Sunu Astuti dan

Hartuti Purnaweni

Universitas Diponegoro produktif, dan berkelanjutan. Tujuan umum tersebut terkandung dua maksud. (1) memperbaiki akses masyarakat terhadap infrastruktur dan fasilitas pelayanan di permukiman kumuh. (2) meningkatkan kesejahteraan masyarakat melalui pencegahan dan peningkatan kualitas permukiman kumuh, berbasis masyarakat, dan partisipasi Pemerintah Daerah. Para Implementor juga menyampaikan Faktor yang mendukung Implementasi Program Kotaku ini adalah adanya ukuran yang jelas hal ini dituangkan dalam $7+1$ indikator kumuh yang bersifat realistis sesuai kebutuhan serta mudah diimplementasikan.

Penghitungan kumuh yang sudah disepakati oleh TIPP juga mempermudah kelancaran Implementasi Program Kotaku di Kelurahan Tanjung Mas. Penghitungan skor kumuh dibawah angka 19 dinyatakan bebas kumuh atau $0 \%$ kumuh.

Disampaikan juga oleh para implementor terdapat beberapa Faktor yang jadi penghambat pencapaian tujuan kebijakan adalah data wilayah/delineasi kumuh di Kelurahan Tanjung Mas tidak update sehingga tujuan kebijakan Pemerintah berdasarkan RPJMN Tahun 2015-2019 yaitu tercapainya pengentasan permukiman kumuh menjadi 0 (nol) hektar tidak dapat tercapai pada tahun 2019. Penanganan kawasan permukiman kumuh Kota Semarang seluas 415,83 Ha. Luasan Kumuh terluas di Kelurahan Tanjung Mas 37,63 Ha. Tujuan ini tidak dapat tercapai di Kelurahan Tanjung Mas, karena masih ada ketidaksesuaian data wilayah yang masuk delineasi kumuh, ada daerah yang di luar delineasi seharusnya masuk dalam wilayah program Kotaku dan perlu ditangani, bahkan daerah yang di luar delineasi itu dirasa jauh lebih kritis daripada daerah yang di dalam delineasi, hal menyebabkan kecemburuan sosial. Meskipun tidak seluruhnya, untuk menanggulangi hal tersebut pihak Kelurahan mengantisipasinya dengan memasukkan wilayah yang tidak masuk delineasi kumuh ke dalam pengajuan program Kelurahan yang diajukan saat Musrenbang.

\section{B. Sumber Daya}

Menurut (Sutrisno, 2014), sumber daya manusia merupakan sumber daya yang memiliki akal perasaan, keinginan, keterampilan, pengetahuan, dorongan, daya, dan karya (rasio, rasa, dan karsa). Keberhasilan implementasi kebijakan bergantung pada kemampuan memanfaatkan sumber daya yang tersedia. Proses implementasi kebijakan menuntut adanya sumber daya manusia 
Jurnal Administrasi Negara

ISSN : 2598-4039 (Online)

ISSN : 2302-2231 (Print)
Herta Sitorus, Retno Sunu Astuti dan

Hartuti Purnaweni

Universitas Diponegoro yang berkualitas sesuai dengan kebutuhan. Sumber daya lain selain sumber daya manusia yang perlu diperhitungkan seperti sumber daya finansial dan waktu.

Dari hasil wawancara dengan para implementor program Kotaku di Kelurahan Tanjung Mas diketahui bahwa salah satu faktor pendukung Implementasi Program Kotaku di Kelurahan Tanjung Mas yaitu memiliki Tim Inti Perencanaan Partisipatif (TIPP) yang kompeten. TIPP sudah memahami visi dan misi program Kotaku. Sebelum Implementasi Program Kotaku, dilakukan bimbingan teknis dan pelatihan kepada para implementor dan TIPP. Pada saat implementasi Program Kotaku berjalanpun dilaksanakan bimbingan teknis secara berkala yang bertujuan untuk menjalin kordinasi dan persamaan persepsi terkait penanganan kawasan kumuh. Pelatihan TIPP, Korkot (Koordinator Kota), Kelompok Swadaya Masyarakat (KSM), Badan Keswadayaan Masyarakat (BKM), Sekretaris BKM diselenggarakan oleh Dinas Perumahan dan Permukiman (Disperkim). Pelatihan dan bimbingan teknis juga diberikan kepada para tukang yang mengerjakan proyek di lapangan. Pelatihan lain yang diberikan yaitu pelatihan komputer, pelatihan kepada Ibu-ibu PKK dan sebagainya. Selain kepada implementor, pelatihan dan penguatan kapasitas juga diberikan kepada organisasi dan masyarakat di Kelurahan Tanjung Mas yang diadakan oleh CSR, pihak pelabuhan dan pihak Indonesia power.

Dari hasil wawancara dengan Pendamping program Kotaku di Kelurahan tanjung Mas diketahui bahwa saat implementasi program Kotaku, masyarakat berpartisipasi aktif memberikan swadaya sesuai dengan kemampuan. Swadaya tersebut dapat berupa konsumsi, tenaga dan uang, serta aktif dalam pengawasan di lapangan. Jika ada kendala masyarakat segera mendiskusikan kepada BKM dan pihak lain yang terlibat. Peran pemerintah juga aktif pada program ini, mulai dari perencanaan, penganggaran, dan pengawasan dilakukan oleh Pemerintah. Selain itu, dalam wawancara disampaikan juga oleh Koordinator Kota program Kotaku bahwa Implementasi program Kotaku juga banyak melibatkan pihak-pihak yang mendukung kelancaran program ini seperti PERKIM mengalokasikan dana khusus untuk pembangunan dan perbaikan sanitasi, PDAM untuk menyediakan pelayanan air bersih, BLH untuk kebersihan lingkungan dan pengangkutan sampah, DKK memberikan fasilitas untuk kebersihan kota, DKK Dinas Kesehatan 
Jurnal Administrasi Negara

ISSN : 2598-4039 (Online)

ISSN : 2302-2231 (Print)
Herta Sitorus, Retno Sunu Astuti dan

Hartuti Purnaweni

Universitas Diponegoro memberikan sosialiasi pola hidup sehat kepada masyarakat.

Sumber daya lain yang sangat penting adalah anggaran. Anggaran mendukung kecukupan investasi dan mendukung tujuan program. Berdasarkan hasil wawancara dengan Koordinator Kota program Kotaku diketahui bahwa sumber pembiayaan Implementasi Program Kotaku di Kelurahan Tanjung Mas berasal dari beberapa sumber, diantaranya adalah; World Bank, APBN, APBD, CSR dan Swadaya Masyarakat. Pembiayaan implementasi program Kotaku di Kelurahan Tanjung Mas mulai diajukan pada tahun 2016 hinggga tahun 2018 sebesar $1 \mathrm{M}$ tiap tahunnya, terbagi menjadi 2 siklus setiap tahunnya. Tiap siklusnya 500 juta digunakan untuk perbaikan insfrastruktur dengan kontrak kerja 90 hari kerja. Teknis pembiayaannya di bawah Perkim ditransfer ke rekening Badan Keswadayaan Masyarakat (BKM). Untuk teknis pencairan dana tidak bisa sekaligus, harus sesuai dengan progres pekerjaan di lapangan.

Berdasarkan wawancara dengan Pendamping Program Kotaku dan salah satu Ketua RW di kelurahan Tanjung Mas diketahui bahwa terdapat kendala saat pelaksanaan program, hal ini terkait dengan akses lingkungan yang sempit menyebabkan bahan-bahan material tidak bisa diangkut sampai lokasi pengerjaan. Bahan-bahan material tersebut hanya bisa di turunkan di jalan besar, selanjutnya menggunakan songko ke dalam gang/ke lokasi pembangunan. Secara tidak langsug selain menghambat progress pekerjaan, juga menyebabkan adanya biaya tambahan untuk langsir material ke lokasi yang akan dibangun, sementara biaya tambahan untuk langsir material tersebut tidak termasuk dalam dana program, sehingga tidak jarang warga melakukan swadaya untuk biaya langsir tersebut.

Selain itu dari hasil wawancara dengan Ketua BKM Kelurahan Tanjung Mas diketahui bahwa sejauh ini mekanisme pencairan anggaran implementasi program Kotaku di Kelurahan Tanjung Mas sudah sesuai panduan yaitu terdapat dua siklus tiap tahunnya. Satu siklus senilai Rp.500.000.000,- digunakan untuk infrastruktur dengan kontrak kerja 90 hari. Sejauh ini anggaran Implementasi Program Kotaku berjalan dengan baik, hanya saja ada beberapa kekurangan dalam anggaran, yaitu dana alokasi Implementasi Program Kotaku disamaratakan dengan Kelurahan lain, padahal Wilayah kumuh Kelurahan Tanjung Mas jauh lebih luas. 
Jurnal Administrasi Negara

ISSN : 2598-4039 (Online)

ISSN : 2302-2231 (Print)
Herta Sitorus, Retno Sunu Astuti dan

Hartuti Purnaweni

Universitas Diponegoro

\section{Karakteristik Agen Pelaksana}

Dari hasil wawancara dengan salah satu Ketua Rw dikelurahan Tanjung Mas diketahui bahwa dalam Implementasi program Kotaku di Kelurahan Tanjung Mas sejauh ini opini publik sangat positif terhadap program Kotaku, hal ini dikarenakan mereka merasakan dampaknya langsung, program Kotaku dapat merubah wajah kelurahan Tanjung Mas menjadi lebih baik. Masyarakat juga menyatakan sejauh ini program Kotaku sudah menjawab apa yang menjadi harapan mereka. Selain itu respon masyarakat terhadap para implementor juga sangat baik hal ini dibuktikan dengan keaktifan dan antusias masyarakat untuk berperan baik melakukan swadaya, maupun barpartisipasi aktif saat program Kotaku diimplementasikan.

\section{Komunikasi Antar Organisasi}

Harold Lasswell dalam karyanya,

The Structure and Function of Communication in Society (Efendy, 2005), cara yang baik untuk menjelaskan komunikasi ialah menjawab pertanyaan sebagai berikut: "Who Says What in Which Channel To Whom With What Effect" atau "Siapa yang menyampaikan, apa yang disampaikan, melalui apa, kepada siapa, dan apa pengaruhnya". Berdasarkan hasil wawancara dengan beberapa Informan diketahui bahwa proses komunikasi dalam implementasi program Kotaku di Kelurahan Tanjung Mas sejauh ini berjalan dengan baik. Contoh komunikasi yang dilakukan adalah laporan progress setiap minggu terkait Implementasi Program Kotaku. Laporan progress kepada Koordinator Kota, Dinas Perumahan dan Permukiman (DISPERKIM), dan BAPPEDA. Adapun content laporan ini adalah capaian kinerja dan kendala yang ditemui dalam pelaksanaan. Komunikasi antar organisasi yang terjalin dengan baik mampu menyelesaikan masalah yang dihadapi dengan cepat. Bentuk komunikasi dalam pelaksanaan sangat beragam namun intinya sama yaitu melakukan kordinasi yang baik dengan beberapa organisasi yang berpartisipasi aktif untuk menghindari tumpang tindih pekerjaan. Komunikasi yang baik akan membuat pekerjaaan lebih efektif dan efesien. Komunikasi yang dijalin saat Implementasi Program Kotaku di Kelurahan Tanjung Mas berdasarkan struktur organisasi atau tingkatan dari masing-masing pejabat, misalnya, RW melakukan komunikasi terlebih dahulu kepada pengampu wilayah terkait kendala maupun kebutuhan pembangunan. Setelah itu, BKM/LPMK dan Kelurahan akan menjembatani ke 
Jurnal Administrasi Negara

ISSN : 2598-4039 (Online)

ISSN : 2302-2231 (Print)
Herta Sitorus, Retno Sunu Astuti dan

Hartuti Purnaweni

Universitas Diponegoro tingkat lebih tinggi yaitu ke tingkat Pemerintah.

Dari hasil wawancara dengan beberapa informan diketahui bahwa terdapat kendala dalam Komunikasi di lapangan, hal ini terkait komunikasi dengan PT KAI, dikarenakan sebagian besar Kelurahan Tanjung Mas khususnya di wilayah Kebon harjo merupakan aset atau lahan milik PT KAI. Sampai saat ini belum ada data yang relevan atas perbatasan atau aset mana yang milik warga atau milik PT KAI. Hal ini membuat para Implementor mengalami keraguan terutama terkait program fisik berupa bangunan di tanah sengketa. Jika tetap dibangun, suatu saat pasti akan digusur dan semua aset akan hilang dan tidak bermanfaat untuk masyarakat. Sejauh ini belum ada komunikasi yang jelas terkait aset tersebut.

\section{E. Kondisi Sosial, Ekonomi Dan Politik}

Berdasarkan hasil wawancara dengan Koordinator Kota Program Kotaku di Kelurahan Tanjung Mas diketahui bahwa sejauh ini kondisi sosial, ekonomi dan politik di Kelurahan Tanjung Mas tidak begitu berpengaruh terhadap Implementasi Program Kotaku di Kelurahan Tanjung Mas. Karena pada dasarnya Implementasi Program Kotaku bersifat kolaborasi dan berbasis masyarakat. Masyarakat yang tidak mampu memberikan sumbangan berupa uang, bahan material atau konsumsi, bisa memberikan sumbangan berupa tenaga. Kondisi sosial sangat mendukung Implementasi Program Kotaku yaitu dilihat dari partisipasi masyarakat yang sangat aktif dan antusias. Kondisi ekonomi masyarakat Kelurahan Tanjung Mas juga meningkat dengan adanya Implementasi Program Kotaku. Program Kotaku banyak memberikan perubahan pada masyarakat Tanjung Mas. Jalan yang sebelumnya becek dan rusak sehingga menghambat aktivitas masyarakat kini sudah sangat bagus dan lancar sehingga masyarakat yang memiliki usaha atau aktivitas lain tidak terganggu. Dengan adanya Program Kotaku berdampak pada peningkatan perekonomian masyarakat di Kelurahan Tanjung Mas.

Keanekaragaman latar belakang masyarakat Kelurahan Tanjung Mas membuat para implementor melakukan rangkaian pendekatan yang berbeda berdasarkan latar belakang masyarakat sesuai dengan latar belakang pendidikan, kondisi sosial, ekonomi masyarakat sehingga Implementasi Program Kotaku dapat diterima dengan baik oleh masyarakat dan dengan dukungan penuh dari Pemerintah. 
Jurnal Administrasi Negara

ISSN : 2598-4039 (Online)

ISSN : 2302-2231 (Print)
Herta Sitorus, Retno Sunu Astuti dan

Hartuti Purnaweni

Universitas Diponegoro
PENUTUP

\section{SIMPULAN DAN REKOMENDASI}

Program Kotaku merupakan platform program yang bersifat Kolaborasi, bertujuan untuk mewujudkan tujuan Nasional pembangunan wilayah permukiman yang tercantum dalam RPJMN 20152019 yaitu menciptakan pemukiman perkotaan yang layak huni dengan mengentaskan pemukiman kumuh hingga 0 hektar. Program ini berfokus pada pengentasan pemukiman yang layak huni tanpa menggusur. Kota Semarang merupakan salah satu yang melaksanakan program Kotaku, hal ini dimuat dalam SK Walikota Semarang Nomor 050/801/2014 tentang Penetapan Lokasi Lingkungan Perumahan dan Permukiman Kumuh Kota Semarang. Luasan wilayah Kumuh di Kota semarang adalah 415,83 Hektar yang tersebar di 15 Kecamatan dan 62 Kelurahan. Wilayah yang luasan kumuhnya paling luas terdapat di Kelurahan Tanjung Mas yaitu 37,63 hektar. Implementasi program Kotaku di Kelurahan Tanjung Mas sejauh ini berjalan dengan baik, hal ini ditunjukkan dengan Proses implementasi program yang dilakukan mulai dari tahapan persiapan, tahapan perencanaan dan tahapan pelaksanaan sudah melalui tahapan yang sesuai dengan pedoman program Kotaku.
Dalam pelaksanaannya terdapat kendala, karena akses lingkungan yang sempit menyebabkan bahan-bahan material hanya bisa diturunkan di jalan besar, hal ini selain menghambat progress pekerjaan, juga menyebabkan biaya tambahan untuk langsir material ke lokasi yang akan dibangun dibebankan kepada wilayah tersebut. Selain itu terdapat juga kekurangan dalam implementasi program ini diantaranya masih ditemukan ketidaksesuaian data wilayah yang masuk delineasi kumuh, ada daerah yang di luar delineasi seharusnya masuk dalam wilayah program Kotaku dan perlu ditangani, bahkan daerah yang di luar delineasi itu dirasa jauh lebih kritis daripada daerah yang di dalam delineasi sehingga menyebabkan kecemburuan sosial. Untuk menanggulangi hal tersebut pihak Kelurahan mengantisipasinya dengan memasukkan wilayah yang tidak masuk delineasi kumuh ke dalam program Kelurahan yang diajukan saat Musrenbang. Kendala juga ditemui di wilayah Tambak lorok yang merupakan bagian dari Kelurahan Tanjung Mas, program Kotaku tidak dapat dilaksanakan di wilayah tersebut dikarenakan telah masuk dalam program Nasional Kampung Bahari. Terdapat juga kendala di lapangan terkait komunikasi dengan PT Kereta 
Jurnal Administrasi Negara

ISSN : 2598-4039 (Online)

ISSN : 2302-2231 (Print)
Herta Sitorus, Retno Sunu Astuti dan

Hartuti Purnaweni

Universitas Diponegoro
Api Indonesia (KAI), dikarenakan sebagian besar Kelurahan Tanjung Mas khususnya di wilayah Kebon harjo terdapat Aset atau lahan milik PT. KAI. Sampai saat ini belum ada data yang relevan atas batas aset mana yang milik warga atau milik PT KAI. Hal ini membuat para Implementor mengalami kebingungan karena takut melaksanakan program terutama program fisik berupa bangunan di tanah sengketa, jika tetap dibangun, suatu saat pasti akan di gusur dan semua aset akan hilang dan tidak bermanfaat untuk masyarakat. Sejauh ini belum ada kordinasi atau komunikasi yang jelas terkait aset tersebut.

Selain kendala tersebut sejauh ini Program Kotaku di Kelurahan Tanjung Mas telah banyak memberikan manfaat bagi masyarakat hal ini dikarenakan program ini telah merubah wajah Kelurahan Tanjung Mas menjadi jauh lebih baik, mempermudah akses dan aktivitas masyarakat. Tanggapan masyarakat sangat positif terhadap program ini, mereka mengatakan bahwa program ini telah menjawab harapan masyarakat. Mereka berharap agar program ini terus dilaksanakan secara berkelanjutan.

Berdasarkan hasil penelitian dan proses analisis Implementasi Program Kotaku di Kelurahan Tanjung Mas Kota
Semarang, terdapat beberapa hal yang harus dibenahi agar tujuan dari program tersebut dapat terlaksana dengan optimal. Atas dasar kondisi tersebut peneliti menyampaikan beberapa rekomendasi, yaitu:

1. Melakukan Updateing atau pembaruan data terkait wilayah yang masuk dalam delineasi kumuh, agar program ini tepat sasaran dan dapat diimplementasikan secara optimal.

2. Melakukan verifikasi ulang dan kerjasama dengan pihak-pihak terkait kejelasan tentang sengketa lahan di Kelurahan Tanjung Mas, hal ini perlu dilaksanakan agar implementasi program Kotaku tidak terhambat dalam pelaksanaan pembangunan di Kelurahan tanjung Mas Kota Semarang.

3. Dalam proses perencanaan program harus dipersiapkan dengan jauh lebih matang, sehingga tidak terjadi tumpang tindih ataupun benturan antar program di lapangan, sehingga proses implementasi program Kotaku dapat berjalan secara optimal sesuai dengan target yang telah ditentukan. 
Jurnal Administrasi Negara

ISSN : 2598-4039 (Online)

ISSN : 2302-2231 (Print)
Herta Sitorus, Retno Sunu Astuti dan

Hartuti Purnaweni

Universitas Diponegoro

\section{REFERENSI}

Adisasmita, R. (2011). Pengelolaan, Pendapatan \& Anggaran Daerah. Graha Ilmu, Yogyakarta.

Agustino, L. (2016). Dasar-dasar kebijakan Publik. Alfabeta. Bandung.

Bathari, A. M., Limba, R. S., \& Mustafa, L. O. (2018). Implementation of the KOTAKU Program: Case Study in Kendari. Publiuho, Vol 1(2), 18-33.

Efendy, O. U. (2005). Ilmu Komunikasi Teori dan Praktek. Remaja Rosda Karya. Bandung.

Irfani, I., \& Winarni, F. (2018). Efektivitas Program Kota Tanpa Kumuh Di Kelurahan Karangwaru Kota Yogyakarta. Adinegara, Vol 7(3), 387-397.

Kementerian Pekerjaan Umum dan Perumahan Rakyat. (2019a). Reformasi Program Kotaku 2019: Minimalis Terfokus. kotaku.pu.go. id/view/7653/reformasi-programKotaku-2019-minimalis-terfokus
Kementerian Pekerjaan Umum dan Perumahan Rakyat. (2019b). Tentang Program Kota Tanpa Kumuh (Kotaku). http://kotaku.pu.go.id/ page/6880/tentang-program-kotatanpa-kumuh-Kotaku

Moleong, L. J. (2010). Metodologi penelitian kualitatif. Remaja Rosdakarya, Bandung.

Sjafrizal. (2009). Teknik Praktis Penyusunan Rencana Pembangunan Daerah. Baduose Media. Jakarta.

Sutrisno, E. (2014). Manajemen Sumber Daya Manusia. Pranada Media Group, Jakarta.

Undang-Undang Dasar Negara Republik Indonesia, Pub. L. No. Pasal 28H Ayat 1 (1945).

Yuliani, S., \& Rosyida, G. P. D. (2017). Kolaborasi dalam Perencanaan Program Kota Tanpa Kumuh (KOTAKU) di Kelurahan Semanggi Kota Surakarta. Wacana Publik, Vol 1(2), 33-47. 